\section{Anti-inflammatory and antinociceptive activities of Euterpe oleracea oil}

\author{
Hugo A. S. Favacho, ${ }^{1,2}$ Bianca R. Oliveira, ${ }^{1}$ Kelem C. Santos, ${ }^{1}$ \\ Benedito J. L. Medeiros, ${ }^{1}$ Pergentino J. C. Sousa, ${ }^{3}$ Fabio F. \\ Perazzo, ${ }^{4}$ José Carlos T. Carvalho ${ }^{*}, 1$
}

\author{
${ }^{1}$ Laboratório de Pesquisa em Fármacos, Universidade Federal do Amapá, \\ Brazil, \\ ${ }^{2}$ Programa de Pós-graduação em Ciências Farmacêuticas, Faculdade de \\ Farmácia, Universidade Federal do Pará, Brazil, \\ ${ }^{3}$ Laboratório de Farmacodinâmica, Faculdade de Farmácia, Universidade \\ Federal do Pará, Brazil, \\ ${ }^{4}$ Departamento de Ciências Exatas e da Terra, Campus Diadema, \\ Universidade Federal de São Paulo, Brazil.
}

Revista Brasileira de Farmacognosia Brazilian Journal of Pharmacognosy 21(1): 105-114, Jan./Feb. 2011

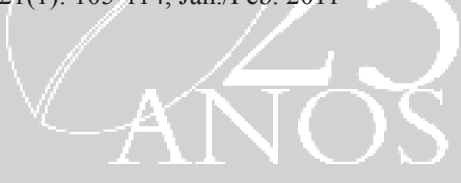

Article

Received 15 Jan 2010

Accepted 28 May 2010

Available online 24 Jan 2011

Keywords: Euterpe oleracea Mart.

oil açaí berry

inflammatory nociceptive Arecaceae

ISSN 0102-695X doi: 10.1590/S0102-695X2011005000007

\section{Introduction}

Euterpe oleracea Mart. popularly known as "açaí" palm tree, occurs naturally in the Amazon region, widely distributed in the floodplain forest of the Amazon estuary that extends to Venezuela and Guyana (Almeida et al., 2004). The fruit of the açai palm tree, known as açai berries, presents considerable potential for the development of new medicines, and it has received a great deal of attention in recent years because of the health benefits associated with its high antioxidant activity and phytochemical composition (Lichtenthaler et al., 2005; Rodrigues et al., 2006; Schauss et al., 2006; Pacheco-Palencia et al., 2007).

The "açaí" palm tree (Euterpe oleracea Mart.) belongs to the family Arecaceae. It is a palm tree that stands out among the palm trees that ornament the
Amazon flora and has been used for subsistence by rural inhabitants (Calzavara, 1972). Different parts of this plant have been used extensively in popular medicine. For example, the oil of the fruit has antidiarrheic action (Plotkin Balick, 1984), and the root, combined with Carica papaya, Citrus sp. (lemon) and Quassia amara, has an anti-malarial agent (Vigneron et al., 2005). A great deal of attention has been given recently to the anti-oxidant capacity of the "açaí" berry and its use as a functional food, in dermocosmetics and even as a nutraceutical (Lichtenthäler et al., 2005; Coïsson et al., 2005; Agra et al., 2007).

The "açaí" berry is characterized by its spherical shape with a diameter of 1.0 to $1.5 \mathrm{~cm}$ and violet color bordering on black. From the third year on, the palm tree produces the fruit, with maximum production in the fifth and sixth years, in two harvests per year: summer 
and winter. Studies revealed that the "açaí" berry is rich in bioactive polyphenols, with special emphasis on the anthocyanins, cyanidin glycosides, cyanidin3-rutoside, cyanidins-3-sambubiosides, feonidin-3rutoside, the proanthocyanidins, like polymers and other flavonoids, orientin, isovitexin, scoparin and taxifolin deoxyhexose (Schauss et al., 2006; Coïsson et al., 2005; Del Pozo-Insfran et al., 2004; Gallori et al., 2004). As antioxidants have shown antiphlogistic properties and attenuate tissue lesion (Conner \& Grisham, 1996; Cuzzocrea et al., 2001), the composition of the oil from the "açaí" berry might be involved in the attenuation of the inflammatory process as well as in nociception.

Unsaturated fatty acids are also present in the "açaí" berry, with oleic acid being the major compound, and palmitic acid as a second major compound (Mantovani et al., 2003; Schauss et al., 2006). Schauss et al. (2006) evaluated the "açaí" in powdered form and observed an inhibitory effect in the cyclooxygenase enzyme of type 1 and 2 in in vitro assays, concluding that "açaí" is a promising anti-inflammatory agent. The oil of Euterpe oleracea contains several phenolic compounds, with special emphasis on vanillic acid, one of the major components. These phenolic compounds have antioxidant properties, which makes this oil a promising addition to food, supplements, cosmetics and medicines (Pacheco-Palencia et al., 2008). The Euterpe oleracea Mart. extracts were also able to inhibit the production of nitric oxide and iNOS expression from culture cells (Matheus et al., 2006). This effect appears to be a consequence of direct action of the extract on the biosynthesis of NO, which has several physiologic activities, such as vasodilation, tumoricid and cytotoxic activities.

In a study conducted by Pacheco-Palencia et al. (2008), it was demonstrated that the chemical composition of "açaí" oil had a significant influence on cell proliferation, suggesting antiproliferative property for polyphenols in cancer cell cultures. In another study, conducted by Del Pozo-Insfran et al. (2004), the antiproliferative and pro-apoptotic activity of the polyphenolic compounds of "açaí" against leukemiacausing HL-60 cells was demonstrated.

In addition to these studies, it was demonstrated that Euterpe oleracea had a vasodilator effect and that this effect was dependent on the activation of the NOGMPC pathway, suggesting the possibility for the use of "açaí" as a medicinal plant in the treatment of cardiovascular diseases (Rocha et al., 2007).

Considering the data presented above, this study aims to investigate the possible anti-inflammatory and antinociceptive effects of E. oleracea Mart. oil.

\section{Material and Methods}

\section{Oil obtainment}

The oil of the Euterpe oleracea Mart., Arecaceae (OEO) fruits was kindly provided by the company Açaí do Amapá Agro-Industrial Ltda Sambazon, located in the city of Macapá, State of Amapá, Brazil. The extraction method consisted of a standardized method used by the company, which was not available to publish because of patent protection.

\section{Analysis of the composition of the OEO}

The OEO was analyzed using a Shimadzu Quadrupole GC/MS system, model QP 5000, with the following programmed conditions: capillary column DB-1 (dimethyl polysiloxane) $30 \mathrm{~m}$ length x $0.25 \mathrm{~mm}$ internal diameter; carrier gas: Helium $(1 \mathrm{~mL} / \mathrm{min}) ; 120$ ${ }^{\circ} \mathrm{C} / 2 \mathrm{~min}$ and $8{ }^{\circ} \mathrm{C} / \mathrm{min}$ up to $290{ }^{\circ} \mathrm{C} / 10 \mathrm{~min}$; injector temperature: $250{ }^{\circ} \mathrm{C}$; detector temperature: $280{ }^{\circ} \mathrm{C}$; oven temperature: $120^{\circ} \mathrm{C}$; injection mode: $0.1 \mu \mathrm{L}(10 \%$ solution), split 1:20; $500 \mathrm{ng} / \mathrm{na}$ column. A sample of 1 $\mu \mathrm{L}$ was injected using a splice type device.

\section{Anti-inflammatory and antinociceptive activities of $O E O$}

\section{Animals}

Male albino Wistar rats weighing between 180$200 \mathrm{~g}$, and male albino Swiss mice (20-25 g), from the Centro Multidisciplinar para Investigação Biológica na Área da Ciência em Animais de Laboratório (Multidisciplinary Center for Biological Investigation in the Area of Science in Laboratory Animals) of the Faculdade de Ciências Médicas of Unicamp, CampinasSP, were used in the various experiments. These animals were fasted for $12 \mathrm{~h}$ before the experiments, with free access to water. The animals were housed in polyethylene boxes with a capacity to accommodate five rats or ten mice, in an acclimatized room $\left(22+2{ }^{\circ} \mathrm{C}\right.$, $55+5 \%$ relative humidity), with periods of light and darkness of $12 \mathrm{~h}$ each, automatically controlled. This study was approved by the Institutional Review Board (IRB) of the Universidade Federal do Amapá, with certification CEP - UNIFAP - 4A /2008 - CD 3720.

Determination of effective dose 50 (ED50) of OEO on writhing test in mice

The ED50 was determined using the writhing test in mice induced by acetic acid (Koster et al., 1959). Groups of mice $(\mathrm{n}=5)$ were treated orally with OEO $(500,1000$ and $1500 \mathrm{mg} / \mathrm{kg})$. Muscular contraction was induced by an intraperitoneal injection of $1 \%$ acetic acid solution $(10 \mathrm{~mL} / \mathrm{kg}) 30 \mathrm{~min}$ after the treatment. The 
number of muscular contractions was counted starting at $5 \mathrm{~min}$ post injection for a period of $20 \mathrm{~min}$. Data represent the average of the total writhes observed.

\section{Rat paw edema}

Groups of rats $(\mathrm{n}=5)$ were treated orally with the OEO ED50 (1226.8 $\mathrm{mg} / \mathrm{kg})$ dose, Indomethacin $(10 \mathrm{mg} / \mathrm{kg}$, MSD Co.), and distilled water $(0.5 \mathrm{~mL})$. After $30 \mathrm{~min}, 1000 \mu \mathrm{g} / \mathrm{paw}$ of carrageenan $(0.1 \mathrm{~mL}$, Iota carrageenan, Fluka, Biochemika) was injected into the right rear plantar region of the rat paws, with an equal volume of saline solution $(0.9 \%)$ into the left rear paw. A digital pachymeter (Zaas Precision) was used to determinate the paw diameter at $1 \mathrm{~h}$ intervals after stimulus application over $6 \mathrm{~h}$.

\section{Granulomatous tissue test}

The induction of granulomatous tissue was described by Meier et al. (1950) and Niemegeers et al. (1975). Three groups of rats $(n=5)$ were used. Pellets weighing approximately $40 \mathrm{mg}$ each were made with $5 \mathrm{~mm}$ of dental cotton tampons. The pellets were sterilized and impregnated with $0.4 \mathrm{~mL}$ ampicillin water solution at the moment of implantation. Animals were anaesthetized, and the pellets were subcutaneously introduced through an abdominal skin incision. Each group was treated daily, for six consecutive days, with distilled water $(0.5 \mathrm{~mL}$, control group), dexamethasone $(0.2 \mathrm{mg} / \mathrm{kg}, \mathrm{MSD}$ Co.) or OEO (1226.8 mg/kg). On the seventh day, the animals were sacrificed, the pellets dissected out and granulomas dried at $60{ }^{\circ} \mathrm{C}$ overnight to determine the dried weight. The difference between the initial and final weights was considered as the weight of the granulomatous tissue produced.

\section{Croton oil-induced dermatitis}

The method described by Tubaro et al. (1985) was used was this experiment. Cutaneous inflammation was induced in different groups of mice with the application of $0.1 \mathrm{~mL}(1 \mathrm{mg} / \mathrm{ear})$ of a croton oil solution (C-4755, Sigma CO.) in acetone on the surface of the right ear. The same volume of acetone was applied to the left ear. Thirty minutes after the stimulus, three groups of mice $(n=10)$ were topically treated with OEO $(1226.8$ $\mathrm{mg} / \mathrm{kg})$, distilled water $(0.1 \mathrm{~mL})$ or dexamethasone $(0.5 \mathrm{mg} / \mathrm{kg})$. Six hours later, the mice were sacrificed and the anti-inflammatory effect evaluated. Samples 8 $\mathrm{mm}$ in diameter were removed using a punch biopsy, and the weight difference between the samples of the control ear (left) and the croton oil-treated ear (right) was established. The results obtained are represented in weight (mg).

\section{Vascular permeability in rats}

This assay was used to estimate alterations of vascular permeability induced by intradermal injections of histamine $(50 \mathrm{mg}$, histamine dihydrochloride, Fluka Ag, Buchs SG). The method used was described by Lykbe and Cummings and modified by Carvalho et al. (1999). This method consisted of the spectrophotometric determination of the amount of extravasated dye in the interstitial space induced by histamine. Groups of rats were treated orally with distilled water $(0.5 \mathrm{~mL}$, control group), Indomethacin (MSD Co., $10 \mathrm{mg} / \mathrm{kg}$ ) or OEO $(1226.8 \mathrm{mg} / \mathrm{kg})$. Evans blue $(25 \mathrm{mg} / \mathrm{kg})$ was then injected intravenously. Histamine was given by intradermal injection into the animal's back $10 \mathrm{~min}$ after the injection of the dye. Each animal received six injections of the same histamine solution in different locations. The animals were sacrificed $20 \mathrm{~min}$ after the last injection. To extract the dye, tissue close to the injection sites was removed $(1.5 \mathrm{~cm}$ diameter), fragmented and placed in tubes containing $3 \mathrm{~mL}$ of formamide, then kept at $37^{\circ} \mathrm{C}$ for $24 \mathrm{~h}$. This material was then centrifuged at $2500 \mathrm{rpm}$ for $15 \mathrm{~min}$. The amount of Evans blue was measured spectrophotometrically at $620 \mathrm{~nm}$. The concentrations of the dye were obtained from the optical density and multiplied by a factor calculated based on the standard deviation.

\section{Cell migration to the peritoneal cavity in rats}

Different groups of animals were treated with OEO (1226.8 mg $/ \mathrm{kg}$, p.o. $)$, dexamethasone $(0.5 \mathrm{mg} / \mathrm{kg}$, p.o.) or distilled water $(0.5 \mathrm{~mL})$, administered $30 \mathrm{~min}$ before the stimulus injection $(100 \mu \mathrm{g} / \mathrm{mL}$ carrageenan, i.p.). The cell migration analysis was based on the method described by Souza \& Ferreira (1985). The results obtained in the differential count were expressed as the number of neutrophils per milliliter of exudates.

\section{Statistical analysis}

The statistical analyses were done using analysis of variance (ANOVA) followed by the TukeyKramer multiple comparison test using Biostat 5.0 $0^{\circledR}$ (2007) software. Results with $p<0.05$ were considered significant. Data are expressed as mean+S.D.

\section{Results}

\section{Analysis of OEO composition}

The chromatographic profile of OEO was taken using a gas chromatography coupled with a mass spectrophotometer. The major compounds identified were palmitic acid $(21.26 \%)$, palmitoleic acid $(2.94 \%)$ 
and oleic acid $(75.796 \%)$. The chromatogram is presented in Figure 1 and relevant data in Table 1.

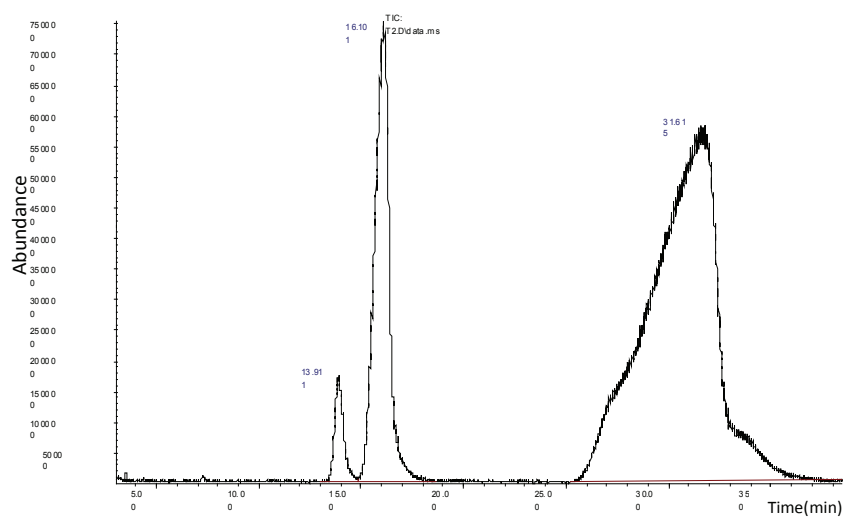

Figure 1. Chromatogram of the fatty acids from oil of Euterpe olereacea Mart., Arecaceae, oil.

Table 1. Identification of chromatogram peaks, retention time and concentration of the major compounds.

\begin{tabular}{ccccc}
\hline Peak N $^{\text {o }}$ & RT & Area & Conc. & Name \\
\hline 1 & 13.908 & 1371815 & $2.941 \%$ & Palmitoleic acid \\
2 & 16.103 & 34959 & $21.263 \%$ & Palmitic acid \\
3 & 31.614 & 47918 & $75.796 \%$ & Oleic acid \\
\hline
\end{tabular}

The data represent the composition of fatty acids from the oil of Euterpe oleracea. The quantification was calculated from the peak area and the results expressed in percentage area, with special emphasis on the predominance of oleic acid.

Determination of effective dose 50 (ED50) of OEO on writhing test in mice

The oral treatment with increasing doses of OEO $(500,1000$ and $1500 \mathrm{mg} / \mathrm{kg})$ in the test of abdominal writhes induced by acetic acid produced a dose-dependent effect with a Pearson's correlation coefficient of $\mathrm{R}=0.9956$ $(\mathrm{y}=0.0219 \mathrm{x}+23.133)$. The ED50 using this test was found to be $1226.8 \mathrm{mg} / \mathrm{kg}$. This result is presented in Figure 2.

The intraperitoneal administration of acetic acid produced a hyperalgesic effect, expressed by the writhing of the back and extension of the rear paws of the animal. The administration of OEO in doses of 500, 1000 and 1500 $\mathrm{mg} / \mathrm{kg}$ produced dose-dependent reduction of writhing by $33.67 \%(p<0.01), 45.88 \%$ and $55.58 \%(p<0.001)$, respectively. The group treated with Indomethacin, a nonsteroidal anti-inflammatory drug, produced a statistically significant inhibitory effect of $85.29 \%(p<0.001)$, as shown in Figure 3.

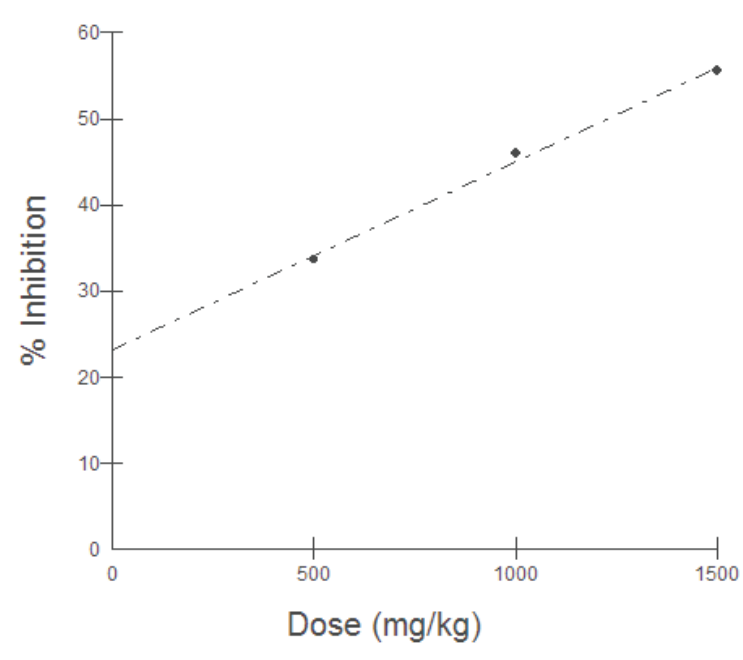

Figure 2. Determination of effective dose 50 in the writhing test in mice with acetic acid. Each point represents the mean percentage of inhibition of the number of writhes ( $n=10 /$ group). $\mathrm{r}=0.9956(\mathrm{y}=0.0219 \mathrm{x}+23,1333)$, and the ED50 found was 1226.8 $\mathrm{mg} / \mathrm{kg}$.

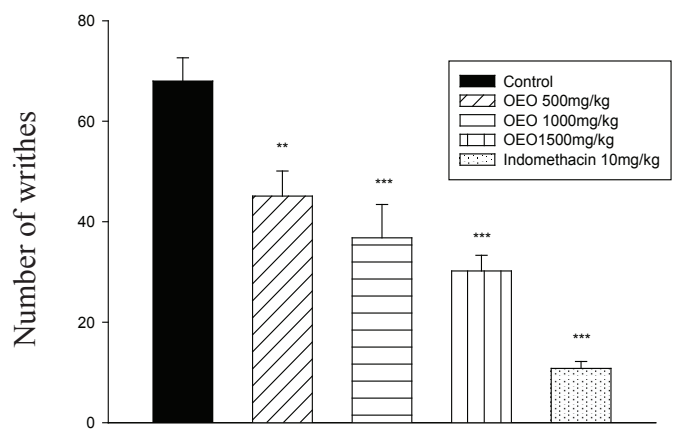

Figure 3. Effect of the administration (p.o.) of OEO (500, 1000 and $1500 \mathrm{mg} / \mathrm{kg})$, indomethacin $(10 \mathrm{mg} / \mathrm{kg})$ and distilled water $(0.5 \mathrm{~mL})$ on writhing in mice induced by i.p. injection of acetic acid $1 \%$. The data is expressed as mean \pm SEM of ten animals. $* * p<0.01, \quad * * * p<0.001 \quad$ (Student-Newman-Keuls multiple comparison test).

\section{Rat paw edema}

Carrageenan injection in the animal paws produced a visible and measurable edema, with a maximum observed $4 \mathrm{~h}$ after the injection of the inflammatory agent. The group treated with OEO at the dose of $1226.8 \mathrm{mg} / \mathrm{kg}$ inhibited edema formation over the $6 \mathrm{~h}$ of the experiment. The maximum edema was inhibited by $29.84 \%(p<0.01)$, compared to the negative control (distilled water), and is presented in Figure 4.

\section{Granulomatous tissue test}

The implantation of the pellets in the subcutaneous region of the animals induced the formation 
of a granulomatous tissue, observed in all the groups at the end of the $7^{\text {th }}$ day. The control group presented a more pronounced formation compared to the treated groups. The daily administration of $1226.8 \mathrm{mg} / \mathrm{kg}$ of OEO over a 6-day period significantly inhibited the formation of granulomatous tissue $(36.66 \%)$ compared to the control group (Figure 5).

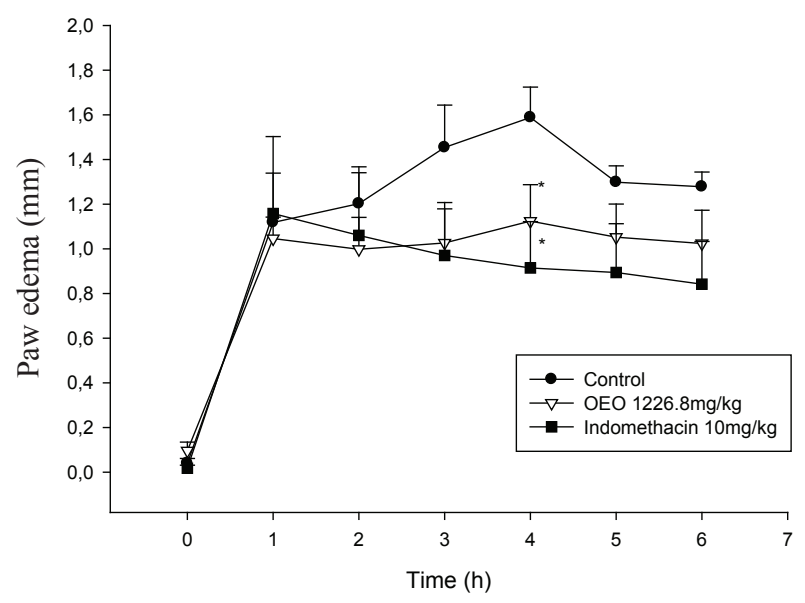

Figure 4. Effect of the p.o. administration of OEO (1226.8 mg/ $\mathrm{kg})$, indomethacin $(10 \mathrm{mg} / \mathrm{kg})$ and distilled water $(0.5 \mathrm{~mL})$ on rat paw edema, induced by the intraplantar injection of carrageenan $(1000 \mu \mathrm{g} / \mathrm{paw})$. The data is expressed as mean \pm SEM of five animals, ${ }^{*} p<0.01$, Student-Newman-Keuls multiple comparison test.

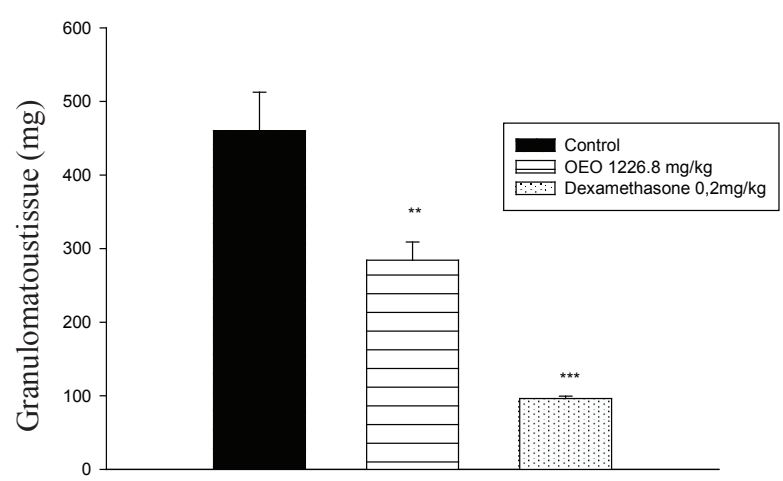

Figure 5. Effect of the administration (p.o.) of OEO (1226.8 mg/ $\mathrm{kg})$, distilled water $(0.5 \mathrm{~mL})$ and dexamethasone $(0.2 \mathrm{mg} / \mathrm{kg})$, for six days on the formation of granulomatous tissue. The bars represent the mean \pm SEM of five animals, ${ }^{* *} p<0.01, * * * p<0.001$, Student-Newman-Keuls multiple comparison test.

\section{Dermatitis induced by croton oil}

The application of croton oil ( $1 \mathrm{mg} /$ ear) produced an intense edema over $6 \mathrm{~h}$. Figure 6 shows that OEO, at the dose of $1226.8 \mathrm{mg} / \mathrm{kg}$, provoked a significant inhibitory effect $(p<0.01)$ compared with the control group. The inhibition of the edematogenic process in the treated group was $37.9 \%$, while dexamethasone, a steroidal anti- inflammatory drug $(10 \mathrm{mg} / \mathrm{kg})$, decreased the inflammatory process by $68.8 \%(p<0.001)$.

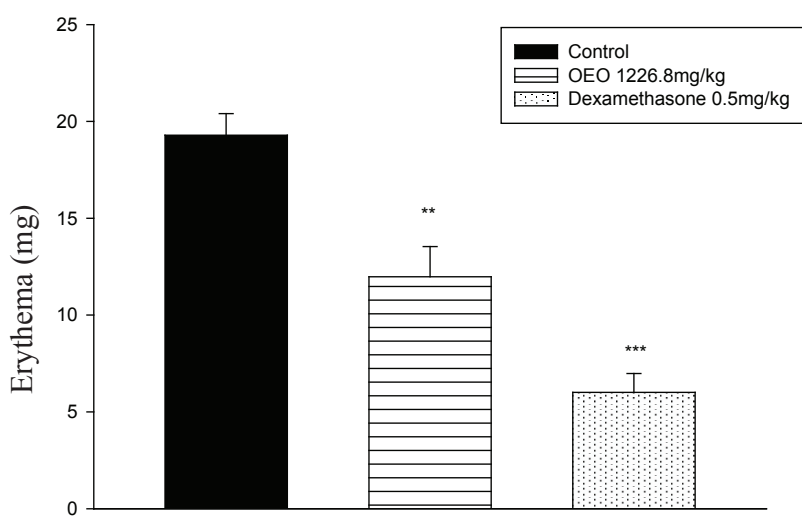

Figure 6. Effect of the administration (p.o.) of OEO (1226.8 $\mathrm{mg} / \mathrm{kg})$ and dexamethasone $(0.5 \mathrm{mg} / \mathrm{kg})$ on dermatitis induced by croton oil in mice. Each column represents the mean $\pm \mathrm{SEM}$ of ten animals. ${ }^{* *} p<0.01,{ }^{* * *} p<0.001$, Student-Newman- Keuls multiple comparison test.

\section{Vascular permeability in rats}

After the application of histamine in the control groups, which were treated only with distilled water, it was possible to observe an increase in vascular permeability, measured by the overflow of the Evans blue dye to the interstitial space. The administration of OEO $1 \mathrm{~h}$ before the application of the inflammatory mediator decreased the response to histamine, inhibiting the vascular permeability by $54.16 \%$. This biological response was significant compared to the control group (Figure 7).

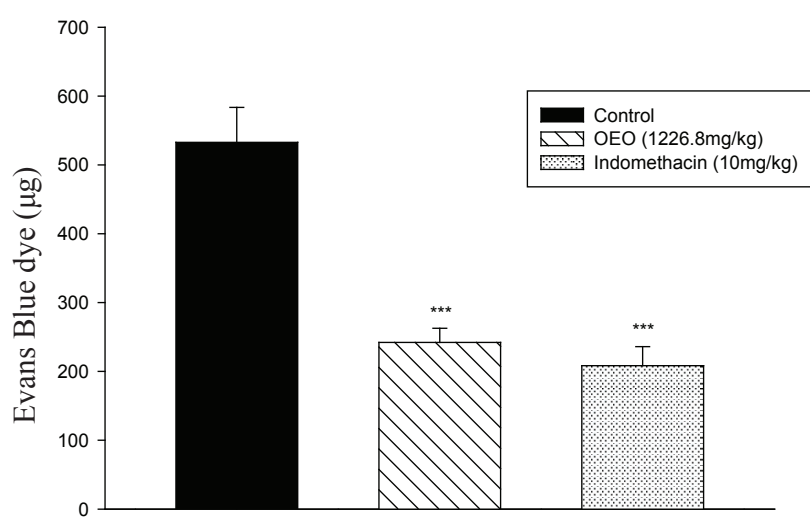

Figure 7. Effect of the administration (p.o.) of OEO (1226.8 $\mathrm{mg} / \mathrm{kg}$, indomethacin $(10 \mathrm{mg} / \mathrm{kg})$ and distilled water, in vascular permeability induced by histamine. The bars represent the mean \pm SEM of five animals. ${ }^{*} p<0,001$, Student-Newman-Keuls multiple comparison test. 


\section{Cell migration to the peritoneal cavity in rats}

In this model of leukocyte migration induced by carrageenan, it was possible to observe an acute inflammatory response in the peritoneal cavity of rats by neutrophil concentration of $3886.58 \times 10^{6}$ cells $/ \mathrm{mL}$ after $4 \mathrm{~h}$. The OEO $(1226.8 \mathrm{mg} / \mathrm{kg})$ significantly inhibited the leukocyte migration $(80.14 \%)$, an effect similar to dexamethasone, which inhibited migration by $93.17 \%$, when compared to the control group treated with distilled water. These observations demonstrated the inhibition of the migration process (Figure 8).

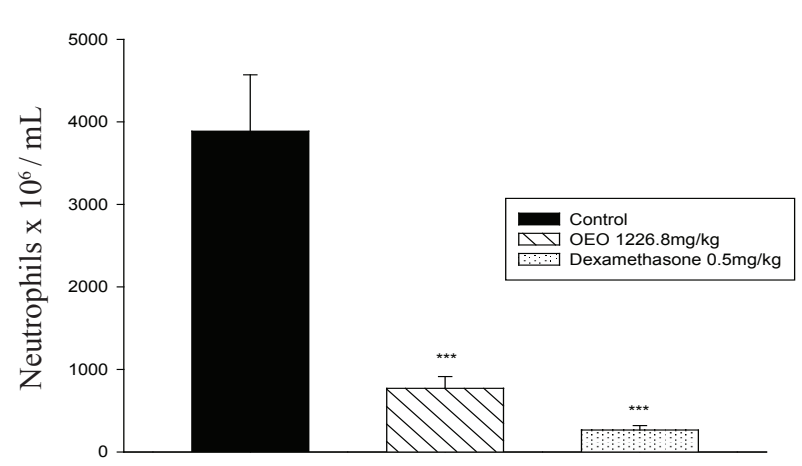

Figure 8. Effect of the administration (p.o.) of OEO $(1226.8 \mathrm{mg} / \mathrm{kg})$ and dexamethasone $(0.5 \mathrm{mg} / \mathrm{kg})$, on the migration of neutrophils to the peritoneal cavity in rats, induced by $3 \mathrm{~mL}$ of carrageenan $(100 \mu \mathrm{g} / \mathrm{mL})$. The bars represent the mean \pm SEM of the number of neutrophils ( $\mathrm{n}=8$ /group). $\quad * * * p<0.001, \quad$ Student-Newman-Keuls multiple comparison test.

\section{Discussion}

The oil of Euterpe oleracea Mart., Arecaceae, has a complex mixture of important fatty acids. In a study conducted by Lubrano et al. (1994), the following components were detected in the composition of the Euterpe oleracea oil: oleic acid (60\%), palmitic acid (22\%), linoleic acid (12\%) and palmitoleic acid (6\%). In the same way, oleic acid $(60 \%)$, palmitic acid $(22 \%)$, palmitoleic acid (2\%), linoleic acid (12\%), stearic acid (2\%) and arachidic acid $(2.5 \%)$ have been identified in other reports. The results of these studies were in agreement to previous results, since the analysis of OEO had identified oleic acid (75.79\%), palmitic acid $(21.26 \%)$ and palmitoleic acid (12.94\%) as the major components of Euterpe oleracea oil.

The fatty acids present in OEO play important physiological roles in the human body, and due to the characteristics of their chemical structure, these compounds have become the focus of interest for pharmaceutical and food companies. In patients with changes in metabolic responses, the balance among the lipids in the diet is intended to control the inflammatory response when exacerbated by the ingestion of unsaturated fatty acids. Fatty acids perform important roles in the modulation of calcium signaling (Soldati et al., 2002), protein kinase C (May \& Calder, 1993), phospholipase C activation and production of inositol-1,4,5-trisphosphate (IP3) and diacylglycerol (DAG). Furthermore, fatty acids are primary precursors of important lipid mediators during the inflammatory process, such as arachidonic acid, prostaglandins, thromboxanes and leukotrienes (Grimble \& Tappia, 1998; O’Shea et al., 2004; Calder, 2003).

Several studies have indicated that the antiinflammatory activities of fatty acids were associated with reductions in the levels of IL- $1 \alpha$, TNF- $\alpha$, IL- 6 and IL- $1 \beta$ (James et al., 2000; Blok et al., 1996). The composition of fatty acids of OEO was comparable with other oils that have anti-inflammatory activities, such as olive oil and fish oil, both rich in fatty acids, when tested in models of ear inflammation induced by croton oil. These results were also observable for antinociceptive effects of palmitic acid as well (James et al., 2000; Blok et al., 1996; Grimble, 1998; Linos et al., 1999).

Oleic acid, one of the constituents of OEO, is a long-chain fatty acid with 18 carbons in its structure. Oleic acid is an essential fatty acid (Omega 9), which participates in metabolism, playing a fundamental role in hormone synthesis. The intake of mono and polyunsaturated fatty acids has been associated with reduced risk of cardiovascular diseases, including hypertension and arteriosclerosis (Basu, et al., 2006). Oleic acid is able to inhibit endothelial cell activation and reduce the expression of inflammatory molecules (Carluccio et al., 1999). Moreover, oleic acid suppresses the release of pro- $\mathrm{NO}$ and $\mathrm{PGE}_{2}$ mediators, as well as the expression of iNOS and COX-2 in LPSstimulated microglial cells. This anti-inflammatory effect of oleic acid is associated with the blockade of reactive oxygen species (ROS) (Oh et al., 2009). Therefore, the importance of the oleic acid present in OEO is due to its role in the inflammatory process (Cardoso et al., 2004; Pereira et al., 2008, OH et al., 2009).

When irritant substances are injected intraperitoneally in mice, a syndrome is manifested characterized by intermittent writhes of the abdomen, twisting of the trunk and extension of the rear paws. Tissue lesion occurs with release of inflammation mediators, including bradykinin, serotonin, histamine and prostaglandins, which are responsible for the induction of the nociceptive stimulus that can be blocked by local anesthetics and analgesic substances (Loux et al., 1978). Moreover, it is believed that the nociception induced by acetic acid depends on the release of cytokines, such as TNF- $\alpha$, IL- $1 \beta$ and IL- 8 , starting from macrophages and basophiles located in the abdominal cavity and, together with other mediators, inducing the characteristic nociception observed in this model (Lei et al., 2008). In 
the writhing assay, treatment with OEO had an antialgic effect. From the dose of $500 \mathrm{mg} / \mathrm{kg}$ up to $1500 \mathrm{mg} / \mathrm{kg}$, this inhibitory effect was statistically significant and dosedependent.

Other models of inducing inflammation are also useful for this activity. Carrageenan induces a measurable local inflammatory response. This is the model of paw edema most commonly used to evaluate the effect of anti-inflammatory drugs. This model presents two inflammatory phases and a third, uncharacteristic one. In the first hour after the carrageenan injection, there is an increase of vascular permeability mediated by histamine and serotonin. In the second hour, the permeability increase is caused by kinines. In the third hour, the increase of vascular permeability occurs due to prostaglandin action (Perazzo et al, 2005).

Carrageenan administration in rat paws induced gradual edema, with the maximum of edema obtained in the fourth hour. The treatment with OEO inhibited the edema at its maximum, suggesting that $\mathrm{OEO}$ interfered in the mechanisms triggered by carrageenan.

Other compounds are also able to induce inflammation. Phorbol esters present in croton oil, like TPA, activate PKC, increase vascular permeability, induce the synthesis of AA metabolites and the expression of COX-2, IL-1 $\beta$, TNF- $\alpha$ and the adhesion molecule ICAM-1 (Tragni et al., 1985). The topical application of croton oil induces a cutaneous inflammatory response, characterized by intense vasodilatation and erythema formation, followed by an increase of the ear thickness as a consequence of the cellular overflow that reaches a maximum in the sixth hour. Tubaro et al. (1985) showed that, in the kinetics of the inflammatory process induced by croton oil, cell infiltration occurs at the peak of edema, and the main cells involved in this process were neutrophils and macrophages. Considering the anti-inflammatory drugs that act in these processes, anti-inflammatory steroids inhibited all the phases, and were more active than non-steroidal drugs.

The hypothesis that mouse ear edema induced by croton oil is due to the mediation of cyclooxygenase products produced by the metabolism of arachidonic acid, could suggest that OEO interferes in this process, thus preventing the generation of these mediators, as it significantly inhibited the formation of the granulomatous tissue (Galey et al., 1985; Inoue et al, 1989; De Young et al., 1989).

The inflammatory process is controlled by the action of a group of chemical mediators, which includes the vasoactive amine, histamine. This mediator is involved in the beginning of inflammation, increasing the vascular permeability. Histamine action starts when it bonds to $\mathrm{H} 1$ histamine receptors present in the endothelial cells, causing the contraction of the endothelial cells and increasing the intercellular spaces, which facilitates the overflow of the substances into the interstitial space. In the permeability test, treatment with OEO decreased histamine action, inhibiting the process by $54.16 \%$ (Figure 7), demonstrating the effectiveness of this oil on the acute inflammatory process.

It is noteworthy to remember that acute inflammation is characterized by vasodilatation, plasma exudation and cell migration to the injured site (Sherwood \& Toliver-Kinsky, 2004). The increase in the vascular permeability leads to a cellular infiltrate, mainly composed of neutrophils, contributing to the inflammatory process through the production, among other mediators, of oxygen-derived free radicals, like the superoxide anion and hydroxyl radicals (Posadas et al., 2004). There are factors that then maintain this increase of vascular permeability. The duration of the inflammatory response provoked by carrageenan is caused by the migration of leukocytes into the tissue, the release of proteolytic enzymes by these cells and generation of PG at the inflammation site. Such factors, besides maintaining the increase in vascular permeability, can cause damage to the conjunctive tissue with the release or formation of additional mediators (Crunkhorn \& Meacock, 1971). Therefore, another important factor for evaluation of the inflammatory response is the migration of inflammatory cells, like neutrophils, to the lesion site.

During the peritonitis process there is an exacerbation of solution transport between plasma and the porous membrane. These alterations are due to vasodilatation of capillaries in the peritoneal membrane and the opening of the pores in microvessels, both caused by cellular and inflammatory mediators, like neutrophils and prostaglandin E2 (Paulino et al, 2008). The inhibition of leukocyte migration to the peritoneal cavity might be related to the inhibition of the production of chemotactic substances and/or inhibition of the expression of adhesion molecules. In the cell migration test, it was demonstrated that the group of animals treated with OEO decreased the number of polymorphonuclear leukocytes (neutrophils) in the peritoneal cavity compared to the control group. The polymorphonuclear leukocytes are the main cells to migrate to the peritoneal cavity in this initial phase of the inflammatory response (Saleh et al., 1999).

Acute inflammation is a fast response to several agents or stimuli that involve the recruitment and activation of neutrophils. However, when the stimulus is not eliminated, the inflammatory process persists and becomes chronic. Chronic inflammation can originate from acute inflammation due to the permanence of the offending agent (Vane, 2002).

The migration of leukocytes to the inflammation site is an important aspect of the inflammatory process. The direct participation of prostaglandins in chemotaxis is unlikely to occur. However, it is known that one of the products of arachidonic acid, leukotriene $\mathrm{B}_{4}$, induces the activation of leukocytes and chemotaxis, and that lipoxygenase, an enzyme that promotes the generation of 
leucotrienes, is sensitive to steroidal anti-inflammatory drugs, like dexamethasone.

Granulomas are granulation tissue nodules composed of fibroblasts, capillaries and modified macrophages. Central necrosis can also be found at these sites. In granuloma formation, there is the initial proliferation of macrophages, which can suffer fusion and give rise to multinucleated cells, occupying the central portion of the granuloma. In the peripheral region there are T lymphocytes, responsible for late hypersensitivity. Blood vessels and fibroblasts proliferate in the peripheral region of the granuloma to nourish it and to provide support to the structure (Flores et al, 1993).

Three phases occurred after the implantation of the pellets in the test animals. The first phase, called the transudative phase, involves the first $3 \mathrm{~h}$ after the implantation; the second, called the exudative phase, occurs between 3 and $72 \mathrm{~h}$; and the third, called the proliferative phase, takes place from $72 \mathrm{~h}$ up to the $6^{\text {th }}$ day (Swingle \& Shideman, 1972).

In view of all the descriptions set out above, the granuloma assay is a chronic inflammatory model, with development inhibited by specific anti-inflammatory drugs, such as steroidal anti-inflammatory drugs. In the granuloma test, the daily treatment with $1226.8 \mathrm{mg} / \mathrm{kg}$ of OEO had a significant inhibitory effect $(p<0.01)$ when compared to the control group. There was no significant difference from the group treated with dexamethasone, demonstrating that OEO acts in a manner similar to steroidal anti-inflammatory drugs and might be involved in the inhibition of phospholipase A2.

\section{Conclusion}

The data obtained for the chemical composition of OEO, together with the mechanisms already described in the literature, suggested the possible involvement of the components of Euterpe oleracea oil in the inflammatory process through the inhibition of mediators derived from arachidonic acid. It can also be suggested that the oil of Euterpe oleracea acts both in acute and chronic inflammatory processes.

\section{References}

Agra MF, Freitas PF, Barbosa-Filho JM 2007. Synopsis of the plants known as medicinal and poisonous in Northeast of Brazil. Rev Bras Farmacogn 17: 28-44.

Almeida SS, Amaral DD, Silva ASL 2004. Análise florística e estrutura de florestas de várzea no estuário amazônico. Acta amazonica 34: 513-524.

Basu A, Devaraj S, Jialal I 2006. Dietary factors that promote or retard inflammation. Arterioscler Thromb Vasc Biol 26: 995-1001.

Blok WL, Katan MB, Van Der Meer JWM 1996. Modulation of Inflammation and Cytokine Production by Dietary (n-3) Fatty Acids, J Nutr 126: 1515-1533

Calder PC 2003. Long-chain n-3 fatty acids and inflammation: potential application in surgical and trauma patients. Braz J Med Biol Res 36: 433-446.

Calvazara BBG 1972. As possibilidades do açaizeiro no estuário amazônico. Bol Fac Ciencias Agrarias 5: $165-230$

Cardoso CR, Souza MA, Ferro EA, Favoreto SJR, Pena JD 2004. Influence of topical administration of $n-3$ and n-6 essential and n-9 nonessential fatty acids on the healing of cutaneous wounds. Wound Repair Regen 12: 235-243.

Carluccio MA, Massaro M, Bonfrate C, Siculella L, Maffia M, Nicolardi G, Distante A, Storelli C, Decaterina $\mathrm{R}$ 1999. Oleic acid inhibits endothelial activation: a direct vascular antiatherogenic mechanism of a nutritional component in the mediterranean diet. Arterioscler Thromb Vasc Biol 19: 220-228.

Carvalho JCT, Sertié JAA, Barbosa MVJ, Patricio KCM, Caputo LR., Sarti SJ, Ferreira LR, Bastos JK 1999. Anti-inflammatory activity of the crude extract from the fruits of Pterodon emarginatus Vog. $J$ Ethnopharmacol 64: 127-133.

Coïsson JD, Travaglia, F, Piana G, Capasso M, Arlorio M 2005. Euterpe oleracea juice as functional pigment for yogurt. Food Res Int 38: 847-853.

Conner EM, Grisham MB 1996. Inflammation, free radicals and antioxidants. Nutrition 12: 274-277.

Crunkhorn P, Meacock CR 1971. Mediators of the inflammation induced in the rat paw by carrageenin. Br J Pharmacol 42: 392-402.

Cuzzocrea S, Riley DP, Caputi AP, Salvemini 2001. Antioxidant therapy: a new pharmacological approach in shock, inflammation, and ischemia/reperfusion injury. Pharmacol Review 53: 135-159.

De Young LM, Kheifets JB, Ballaron SJ, Young JM 1989. Edema and cell infiltration in the phorbol estertreated mouse ear are temporally separate and can be differentially modulated by pharmacologic agents. Agents Actions 26:335-341.

Del Pozo-Isfran D, Brenes CH, Talcott ST 2004. Phytochemical composition and pigment stability of açaí (Euterpe oleracea). J Agric Food Chem 54: 1539-1545.

Flores CA, Zappellini A, Prado-Franceschi J 1993. Lipoxygenase derived mediators may be involved in in vivo neutrophil migration induced by Bothrops erythromelas and Bothrops alternatus venoms. Toxicon 31: 1551-1559.

Galey GI, Ziboh VA, Marcelo CI, Voorhees JJ 1985. Modulation of phospholipid metabolism in murine keratinocytes by tumor promoter, 12-O-tetradecanoyl13-acetate. J Invest Dermatol 85: 319-323.

Gallori S, Bilia AR, Bergonzi MC, Barbosa WLR, Vincieri FF 2004. Polyphenolic constituents of fruit pulp of Euterpe oleracea Mart. (açai palm). Chromatographia 59: 739-743.

Grimble RF, Tappia PS 1998. Modulation of pro-inflammatory cytokine biology by unsaturated fatty acids. $Z$ Ernahrungswiss 37: 57-65.

Inoue H, Saito K, Koshihara Y, Muroto S 1986. Inhibitory effect of glycyrrhetinic acid derivatives on 
lipoxygenase and prostaglandin syntetase. Chem Pharm Bull 34: 897-901.

James MJ, Gibson RA, Cleland LG 2000. Dietary polyunsaturated fatty acids and inflammatory mediator production. Am J Clin Nutr 71: 343-348.

Koster R, Anderson M, DeBeer EJ 1959. Acetic acid analgesic screening. Fed Proceedings 18: 418-420.

Lei G, Caiying Y, Wenying C, Hua Y, Ru Z, Juan L, Huifen Y, Xiaoli Y, Dechang Z 2008. Anti-inflammatory and analgesic potency of carboxyamidotriazole, a tumoristatic agent. J Pharmacol Exp Ther 325: 1016.

Lichtenthäler R, Belandrino R, Maia J, Papagiannopoulos M, Fabricius H, Marx F 2005. Total antioxidant scavenging capacities of Euterpe oleracea Mart. (açaí) fruits. Int J Food Sci Nutrition 56: 53-64.

Linos A, Kaklamani VG, Kaklamani E 1999. Dietary factors in relation to rheumatoid arthritis: a role for olive oil and cooked vegetables. Am J Clin Nutr 70: $1077-$ 1082.

Loux JJ, Smith S, Salem H 1978. Comparative analgesic testing of various compounds in mice using writhing techniques. Arzneimittelforschung 28: 1644-1647.

Lubrano C, Robin J, Khaiat A 1994. Composition en acides gras, sterols, et tocopherols d'huiles de pulpe de fruits de six especes de palmiers de Guyane. Oleagineux 49: 59-65.

Lykbe AMJ, Cummings R 1969. Inflammation in healing. 1. Time - course and mediation of exsudation in wound healing in the rat. Brit J Exp Pathol 50: 309-318.

Mantovani ISB, Fernandes SB, Fernandes SBO, Menezes FS 2003. Constituintes apolares do fruto do açaí (Euterpe oleracea M. - Arecaceae). Rev Bras Farmacogn 13: 41-42.

Matheus ME, Fernandes SBO, Silveira CS, Rodrigues VP, Menezes FS, Fernandes PD 2006. Inhibitory effects of Euterpe oleracea Mart. on nitric oxide production and iNOS expression. J Ethnopharmacol 107: 291-296.

May CL, Calder PC 1993. Unsaturated fatty acids inhibit lymphocyte protein kinase C activity. Biochem Soc Trans 21: 377S.

Meier R., Schuler W, Desaulles P 1950. L-Usnic Acid: tumor inhibitor isolated from Lichens. Experimentia 6: 469471.

Niemegeers CJE, Awouters F, Lenaerts FM, Janssey AJ 1975. The activity of suprofen on nystatin-induced paw oedema in rats. Arzneimittel-Forschung 23: 15161519.

O'Shea M, Bassaganya-Riera J, Mohede IC 2004. Immunomodulatory properties of conjugated linoleic acid. Am J Clin Nutr 79: 1199-1206.

Oh YT, Lee JY, Lee J, Kim H, Yoon KS, Cho W, Kang I 2009. Oleic acid reduces lipopolysaccharide-induced expression of iNOS and COX-2 in BV2 murine microglial cells: possible involvement of reactive oxygen species, p38 MAPK, and IKK/NF-kappa B signaling pathways. Neurosci Lett 464: 93-97.

Pacheco-Palencia LA, Talcott ST, Safe S, Mertens-Talcott $S$ 2008. Absorption and biological activity of phytochemical-rich extracts from Açaí (Euterpe oleracea Mart.) pulp and oil in vitro. J Agric Food
Chem 56: 3593-3600.

Pacheco-Palencia L, Hawken P, Talcott ST 2007. Phytochemical antioxidant and pigment stability of açai (Euterpe oleracea Mart.) as affected by clarification, ascorbic acid fortification and storage. Food Res Int 40: 620-628.

Paulino N, Abreu SRL, Uto Y, Koyama D, Nagasawa H, Hori H, Dirsch VM, Vollmar AM, Scremin A, Bretz WA 2008. Anti-inflammatory effects of a bioavailable compound, Artepillin C, in Brazilian propolis. Eur $J$ Pharmacol 101: 1-6.

Perazzo FF, Souza GHB, Lopes W, Cardoso LGV, Carvalho JCT, Nanayakkara NPD, Bastos JK 2005. Antiinflammatory and analgesic properties of waterethanolic extract from Pothomorphe umbellata (Piperaceae) aerial parts. J Ethnopharmacol 99: 215220.

Pereira ML, Hatanaka E, Martins EF, Oliveira F, Liberti EA, Farskv SH, Curi R, Pithon-Curi TC 2008. Effect of oleic and linoleic acids on the inflammatory phase of wound healing in rats. Cell Biochem Funct 26: 197204.

Plotkin MJ, Balick M 1984. Medicinal uses of South American palms. J Ethnopharmacol 10: 157-179.

Posadas I, Bucci M, Roviezzo F, Rossi A, Parente L, Sautebin L, Cirino G 2004. Carrageenan-induced paw oedema is biphasic, age-weight dependent and displays differential nitric oxide cyclooxygenase-2 expression. Br J Pharmacol 142: 331- 338.

Rocha APM, Carvalho LCRM, Sousa MAV, Madeira SVF, Sousa, PJC, Tano T; Schini-Kerth VB, Resende AC, Soares De Moura R 2007. Endothelium-dependent vasodilator effect of Euterpe oleracea Mart. (Açaí) extracts in mesenteric vascular bed of the rat. Vasc Pharmacol 46: 97-104.

Rodrigues R, Lichtenthäler R, Zimmermann B, Papagiannopoulos M, Fabricius H, Marx F, Maia J, Almeida O 2006. Total oxidant scavenging capacity of Euterpe oleracea Mart. (açaí) seeds and identification of their polyphenoliccompounds. J Agric Food Chem 54: 4162-4167.

Saleh TSF, Calixto JB, Medeiros YS 1999. Effects of antiinflammatory drugs upon nitrate and myeloperoxidase levels in the mouse pleurisy induced by carrageenan. Peptides 20: 949-956.

Schauss A, Wu X, Prior R, Ou B, Patel D, Huang D, Kababick J 2006. Phytochemical and nutrient composition of the freezedried amazonian palm berry Euterpe oleracea Mart. (açai). J Aqric Food Chem 54: 8598-8603.

Sherwood ER, Toliver-Kinsky T 2004. Mechanisms of the inflammatory response. Best Pract Res Clin Anaesthesiol 18: 385-405.

Soldati L, Lombardi C, Adamo D, Terranegra A, Bianchin C, Bianchi G, Vezzoli G 2002. Arachidonic acid increases intracellular calcium in erythrocytes. Biochem Biophys Res Commun 293: 974-978.

Souza GEP, Ferreira SH 1985. Blockade by antimacrophage serum of the migration of PMN neutrophilis into the inflamed peritoneal cavity. Agents Actions 17: 97103.

Swingle KF, Shideman FE 1972. Phases of the inflammatory 
response to subcutaneous implantation of a cotton pellet and their modification by certain antiinflammatory agents. Pharmacol Exp Ther 13: 226234.

Tragni E, Tubaro A, Melis S, Galli CL 1985. Evidence for an anti-inflammatory action of a natural extract utilizing two classic irritation tests. Food Chem Toxicol 23: 317-319.

Tubaro A, Dri P, Delbello G, Zilli C, Della Loggia R 1985. The croton oil ear test revisited. Agents Actions 17: 347-349.

Vane JR 2002. Nomenclature for COX-2 inhibitors. Lancet 356: 1373.

Vigneron M, Deparis X, Deharo E, Bourdy G 2005. Antimalarial remedies in French Guiana: A knowledge attitudes and practices study. J Ethnopharmacol 98: 351-360.

\section{*Correspondence}

José Carlos T. Carvalho

Laboratório de Pesquisa em Fármacos, Universidade Federal do Amapá, Rod. JK, km 2, 68902-380, Macapá-AP, Brazil farmacos@unifap.br 